\title{
EXPLORING BEGINNER EFL TEACHER IN MAKING LESSON PLAN FOR FIRST YEAR STUDENTS OF PUBLIC SENIOR HIGH SCHOOL IN MAKASSAR
}

\author{
Yunitari Mustikawati \\ yunitari@unm.ac.id \\ Universitas Negeri Makassar, Indonesia
}

\begin{abstract}
This study aims at exploring the Beginner EFL teacher in making learning objective, selecting learning materials, and assessment used in learning, and discovering the problems and solutions of the Beginner EFL teacher. This study is qualitative research with a case study. Data sources of the study were one Beginner EFL teacher of SMAN A (pseudonym), the Vice Principal of SMAN A, and the Head of MGMP Makassar. Data were collected by employing observation, interview, questionnaire, and documentation. The results of the study reveal that the Beginner EFL teacher has a problem in formulating clear learning objective and in using appropriate assessment to students' achievement. However, he has adequate knowledge of selecting the materials from the easiest to the most challenging one. The solutions to overcome the problems of the Beginner EFL teacher are to provide supervisor (superintendent) with the same discipline in school, assign qualified experienced teacher as mentor teacher to guide the Beginner EFL teacher in his first year of teaching, and assign the Beginner EFL teacher to join MGMP and attend its monthly meetings as a compulsory activity.
\end{abstract}

Keywords: Beginner EFL teacher, lesson plan, learning objective, learning material, assessment

\section{INTRODUCTION}

The failure and success in learning and teaching languages rely on several components. Strevens (1987:12-23) mentioned four basic components, namely the community, the profession, the teacher, and the learner. However, in my personal view, the teacher is the key component because the teacher has major influence in creating the learning to produce qualified learners. The former Minister of Culture and Primary and Secondary Education of the Republic of Indonesia, Baswedan (Kompas, December 2014) described that the condition of education in Indonesia is in the state of emergency. He referred to the data of Ministry of Culture and Education that in recent years, education in Indonesia shows poor results, one among others is the average value of teacher competence in Indonesia is 44.5; in fact, the teacher competency standard should be 75 . This condition should then be taken seriously. Therefore, the quality improvement in education should start from a teacher.

The government of Indonesia has introduced Law No.14/2005 to improving teacher development. Article 1 Clause 10 states that competence is a set of knowledge, skills, and behaviors a teacher or lecture must have, fully comprehend and master to perform his/her professional tasks. Teachers' quality gives an impact on the quality of students' learning. "Good quality of teachers can produce good quality of students, and then the poor quality 
of teachers can contribute to the poor achievement of students" (Jalal et.al, 2009:7). The process of learning will be effective if the teacher plans the lessons carefully. Hunter (1994) states that planning is as important in the classroom as it is in other areas of life. "Skill in planning is acknowledged to be one of the most influential factors in successful teaching" (Hunter , 1994:3). It means that teaching with a careful plan where objective becomes the criteria by which material is selected, content is outlined, instructional procedures are developed and assessment is prepared will lead to better learning for students.

The importance of planning the lessons is mentioned by several researchers (Marzano, 2010; Schoenfeldt et.al, 2009; Skowron, 2006; Richards, 2002; Nunan \& Lamb, 1996; Nunan, 1991; Clark \& Yinger, 1987; Taylor, 1970; Tyler, 1949). Planning the lessons is a rational process that tries to provide teaching for students' learning. Thoughtful decisions are made when a teacher plans a lesson based on the knowledge and skills of the teacher (Schoenfeldt et.al, 2009:6).

Numerous studies have investigated about non-Beginner teachers (McClutcheon and Milner 2002; Brown, 1990; Yinger, 1980; McCutcheon, 1980; Zahorik, 1975; Taylor, 1970;). Very few studies have attempted to examine planning practices by Beginner teachers. The studies mainly examine both non-Beginner teachers and Beginner teachers (Richard, 1998; Brown, 1993; Livingstone and Borko, 1989). Studies on English lesson plan in senior high schools particularly in Indonesia context are very few (Prajas, 2009; Pujiono, 2013). The studies mainly used the ready-made lesson plan collected from the teachers to be examined without finding out the on-site lesson plan for further investigation. Prajas (2000), Pujiono (2013), and Mustikawati (2018) had similar findings based on ready-made lesson plan document which is the senior high school EFL teachers are in good categories in constructing English lesson plan. However, this research will investigate further about the on-site lesson plan made by the Beginner EFL teacher to discover how the Beginner teacher constructs his lesson plan before teaching. Thus, this research specifically asks the following questions: (1) How does the Beginner EFL teacher in public senior high school in Makassar plan his lesson in terms of articulating clear learning objective, organizing learning materials, and assessment used aligned with learning objective? (2) What are the problems and solutions of the Beginner EFL teacher?

It is important to conduct this study because the study reveals the way Beginner EFL teachers planning EFL lessons, problems they encounter during the planning, and ways to solve the problems. By having rich data from the first hand source, the Beginner EFL teachers, the quality of teachers can optimistically be improved.

\section{LITERATURE OF REVIEW}

Pedagogical knowledge of a teacher plays an essential role in language teaching. Based on the teacher's understanding and the depth of comprehension on his pedagogical knowledge, he will decide how to create the desired lesson plan which leads to effective teaching. Teaching is effective when the objective of the lesson is achieved.

Rovegno (2003:426-449) defines teachers' knowledge as practical, personal, complex, and situated. As teachers develop their knowledge, it becomes more connected and detailed. Pedagogical content knowledge develops as a result of teachers' connecting, organizing, and making sense of what they know. She also discusses knowledge of expert teachers that experts have more knowledge and know more details about the concept that 
they understand. Experts are able to make more connections on broad issues. They also have situated knowledge because their decisions are based on clues that arise in the context. Experts know about their subject and they know how to teach it as well. Their knowledge is influenced by their prior knowledge, prior experiences, and school context. The ability to understand "the big picture... develops over time and is a sign of expertise" (Rovegno, 2003:307).

Several scholars address practical knowledge, the knowledge teachers have of their own situations. This important concept concerns the knowledge teachers have of their classroom situations and the practical dilemmas they face in carrying out action in those settings (Carter,1990:299). Teachers make complicated interpretations and decisions under conditions of inherent uncertainty (Doyle, 1986). Thus, to plan, teachers engage in practical thinking that leads to an action appropriate to the particular situation. Carter (1990:300) believes practical knowledge is shaped by "teachers' personal history, which includes intentions and purposes, as well as the cumulative effects on life experience". Clandinin (1992:125) believes that teachers' personal practical knowledge is constructed through "the person's past experience, the person's present mind body, and the person's future plans and actions". It takes into consideration of a person's prior knowledge and it is highly situational.

Ennis (1994:164-175) shares her notion about curriculum expertise which is based on three types of knowledge. Those are declarative, procedural, and conditional. Declarative is factual or subject matter knowledge. Procedural knowledge is the knowledge of how to do something. Conditional knowledge is the type of knowledge about when to do certain things and why. Thus, it is a more practical pedagogical type of knowledge.

\section{METHOD}

This research employed qualitative research with a case study approach because it examined a phenomenon focusing on a specific case; it examined in-depth of a phenomenon in its natural context; it helped to understand context characteristics of the issue and discovered what could be learned from the case, and it was based on etic and emic perspectives of the study (Merriam, 1988; Stake, 1994; Gall et.al, 2005).

In selecting the samples, the study employed criterion-based selection (LeCompte \& Preissle, 1993) to obtain rich information concerning planning EFL lessons. The characteristics of the participants were: the participants were the Beginner EFL teachers who teach in public senior high schools in Makassar, they have zero to a maximum of five years of teaching experiences in public senior high schools, and they have an undergraduate certificate (S1 Sarjana degree) especially in English Education. Gender, age, social status, and working status (permanent/non-permanent) were not considered for recruiting the participants in this study. Based on those criteria, the study obtained three Beginner EFL teachers. However, one participant could not participate due to her hectic schedule and one participant got accepted to work in a new place out of town; thus, one Beginner EFL teacher called by the name of Muhlis of SMAN X (pseudonym, due to the objection of the subject to reveal the real name) was the research subject. 
The data were collected through KTSP lesson plan documents, questionnaire, interview, and observation. The trustworthiness of the study was conducted into three parts, namely triangulation, thick description, and member checks. In triangulation, multiple data collection methods and data sources were utilized to check the findings of the case study as evidence of truthfulness (Merriam, 1998:207). Yin (2003) also suggested that in case studies the use of multiple sources of evidence allows for many lines of inquiry to converge together. So, other sources in this study were the vice principal of the school where Muhlis works, the Head of Secondary School Subject Teachers' Working Group of Makassar, questionnaire, and interview. This study also provided a rich, thick description of the phenomenon that what Gall, Gall, and Borg (2005:306) illustrated the "situation and its context and gave readers a sense of the meanings in that situation". The researcher then checked the participants' perspectives by member checking, where participants reviewed the statements in the writer's report for accuracy and completeness. It is an essential procedure to ensure deep understanding of teachers planning EFL lessons and the accuracy of the findings. Member checking may reveal factual errors that can be corrected. It is possible that EFL teachers may recall new facts about their situation when reading the report. Therefore, the report was re-written to obtain additional information as needed (Gall, Gall, and Borg, 2005; Merriam, 1998)..

\section{RESULT AND DISCUSSIONS}

\section{A. The way the Beginner EFL teacher plans his lessons}

\section{a. Learning Objective}

In terms of the learning objective formulated, Muhlis wrote in his lesson plan: to make students review the lesson taught previously, the use of to be, present tense, adjective, noun, article, apostrophe, and matching words (lesson plan document based on observation).

Based on what Muhlis stated in his lesson plan, it is discovered that he did not use the behavioral verb or action verb in articulating clear objective, it is difficult to be measured, and unobservable. In fact, those three elements are needed to make clear lesson objective as Gronlund (2004:4) stated that "at the end of the lesson students be able to demonstrate that they have learned what was expected of them" and it should be measurable and observable of students' performance. The students must perform to demonstrate that the objective has been mastered (Bloom et.al, 1956; Gronlund, 2004).

Lack of understanding of knowledge in formulating specific learning objective of the lesson which is shown by Muhlis is also supported by his revelation in the questionnaire. He considered himself as "Less Competent" when assessing himself concerning formulating clear lesson objective. He admitted that he did not know how to make lesson plan by saying, "Oh, to tell the truth, no [in make lesson plan]" (interview), when he was asked whether he knows how to make it.

Besides lack of knowledge, Muhlis also lacks skills which are related to practical knowledge shaped by his personal history. Before teaching at public senior high school, he had experiences in teaching English in Islamic boarding schools (pesantren). The 
principals did not require him to make the lesson plan but suggested him to focus more on having the discussion in class.

"I like teaching English in general. I like [to teach in] private school err boarding school. Your know the language is not important, I mean the way it's not important. What is important is what we mean [by it]. And then he [the principal] said to me to just give the students topic every week, you just discuss it. That's [what] I like" (interview).

This finding indicated that did not get used to practicing making lesson plan since working in Islamic boarding schools. The habits of not making lesson plan were built without Muhlis realizing it; thus, lack of knowledge and lack of practice caused Muhlis unable to formulate clear lesson objectives.

\section{b. Learning Materials}

In terms of selecting learning materials, Muhlis wrote the arrangement of learning materials to be used in his lesson plan in an observation session as follows:

Exercise 1 is to complete the sentences with the correct form of the Present Simple,

Exercise 2 is to complete the sentences with the correct form of there (isn't/aren't),

Exercise 3 is to complete the sentences using a possessive adjective or possessive pronoun,

Exercise 4 is to complete the sentences with the articles of a, an, or the,

Exercise 5 is to complete the sentences with the correct prepositions,

Exercise 6 is to put in apostrophes where necessary,

Exercise 7 is to complete the table of nouns and adjectives,

Exercise 8 is to match the words of correct compound nouns.

(On-site lesson plan document)

He explained the arrangement of the learning material he made:

"We must choose [from the book] the most important one and you organize [the materials]" (interview)

Then continued:

"I arrange the easiest exercise first, then getting difficult, getting difficult, and getting difficult to raise the challenge of the students. I mostly take the materials from the textbook [provided]" (interview)

Based on the aforementioned data, it is discovered that Muhlis has sufficient knowledge and skills in organizing the learning materials. It is in line with Gagne and Briggs (1979) suggestions to make the hierarchies in organizing the order of learning materials. The hierarchies describe the sequences from easy to difficult or from simple to complex. The teacher will see the gradual achievement shown by the students from the easiest task to the most challenging one to achieve the objective of the lesson. 


\section{c. Learning Assessment}

In terms of learning assessment, Muhlis wrote in his lesson plan in the assessment section: students are able to solve correctly the questions given about the lessons given (lesson plan document based on observation).

Further in the interview he revealed: "I don't understand why we have to plan the evaluation. But I evaluate by seeing the true of false of the correct answers."

When Muhlis was asked how he acknowledged that the students have learned what he intended them to learn, he responded:

"..Uh, if, I found out that they are making many mistakes, so that means they don't understand. Yeah, and I will explain again. But, if I found out that they uh they make correct answer, just a little bit false, a little bit incorrect, that's an indication that they understand"

Based on those aforementioned findings, it is discovered that Muhlis lacked comprehension in the evaluation system because he said he did not understand why the evaluation should be planned. He merely evaluated based on the numbers of correct answers to indicate that the students have mastered the lesson. The findings imply that Muhlis has limited knowledge and skills in language assessment. In fact, the assessment is a very important part of lesson planning to improve student learning.

\section{B. Problems and Solutions of the Beginner EFL teacher in planning EFL lessons}

In this section, the writer will inform the problems discovered in the research followed by the solutions concerning the Beginner EFL teacher in planning lesson.

First problem: Muhlis lacks knowledge and skills especially in formulating clear lesson objective and assessing students' achievement. He did not use a behavioral verb, cannot be measured, and unobservable; whereas, in the assessment he merely applied true or false answers as an indicator whether the students have understood the lesson or not. The solution for the problem is the Beginner EFL teacher needs to join MGMP (Secondary School Subject Teachers' Working Group) and attend the meeting which is conducted monthly. The MGMP is a free of charge forum for subject teachers, in this case is English, where teachers can share their knowledge and skills for teacher development. It facilitates EFL teachers to improve teachers' ability and skills to prepare, implement, and evaluate the learning process. So far, the MGMP has conducted trainings for four skills of language.

Second problem: the school lacks attention concerning lesson plan submitted annually in terms of whether the lesson plan is made by the teacher or someone else and no feedback for revision as it revealed by the data sources below:

Muhlis, "I didn't make (it/lesson plan)". Then he revealed that he did not make his lesson plan. Someone else, an English teacher, made the lesson plan for him to be submitted to the school. Muhlis gave the lesson plan to the Vice-Principal of Curriculum Affair. The Vice-Principal merely checked the lesson plan whether the teacher had signed it. Then, the signed lesson plan would be handed to the Principal to be signed (interview). 
The vice principal:

"So, they (teachers) make them (lesson plan) according to the curriculum, the prevailing (curriculum). However, if the curriculum is, say it is effective in the year 2000 and the 2000 (lesson plan) has been approved, in the year 2001 they will just copy it, in 2002 (they will) just copy (it), copy (it), copy (it), and so on" (interview).

"No, nothing so called revision." "Nothing, because the one who signed (was from) the curriculum. After (the lesson plan was) submitted to the principal, no more, it's done, not checked" (interview).

and the supervisor (superintendent) who conducted academic supervision has different discipline with the Beginner EFL teacher, so it is quite difficult for Beginner EFL teacher to develop rapidly. The solution to this problem is the school needs to have the same discipline for a supervisor if the school wanted to improve teacher development. The supervisor can give valuable feedback on the content of the lesson plan if he has the same background discipline as the teacher. Thus, the learning will be meaningful for Beginner EFL teacher and the teacher will gradually develop in terms of knowledge and skills. Another solution that can be applied is to provide mentor teacher for the Beginner EFL teacher to discuss the problems encountered in school which is still related to teaching and learning process including lesson plan. The mentor teacher is taken from the experienced teacher who has adequate knowledge and skills for mentoring the Beginner teacher. The objective of a mentor teacher is to guide the Beginner teacher in his first year of teaching in school.

\section{CONCLUSIONS, IMPLICATION, AND SUGGESTIONS}

The conclusions of the study based on the findings and discussions of the research are the Beginner EFL teacher has a problem in formulating clear learning objective. He is unable to use behavioral verbs, unmeasured, and unobservable. He has difficulty in using appropriate assessment to students' achievement. He merely uses the correct answers obtained as the indicator that his students understand the lesson or not. However, he has adequate knowledge in organizing learning materials to arrange the materials from the easiest to the most challenging one. His prior experiences in Islamic boarding schools, in this case not making lesson plan before teaching which was encouraged by the principals, had at least given contribution on his less skillfulness in formulating appropariate lesson plan. In addition, the lesson plan submitted to the school did not get any feedback so the Beginner teacher did not know his development on making an appropriate lesson plan.

Based on the results of the study, the researcher proposes suggestions that the Beginner EFL teacher needs to join MGMP and attend the monthly meetings. It is a positive thing if the school makes it as a compulsory for Beginner teacher to join the activity because the MGMP helps to improve teachers' ability and skills to prepare, implement, and evaluate the learning process. It is a forum to share 
problems and solutions concerning teaching instruction and to gain current information as a reference for teacher development.

The Beginner EFL teacher needs a kind of mentor, relying solely on school's supervisor is quite difficult concerning different discipline, so it is suggested that the school can assign experienced teacher as a mentor teacher to assist Beginner teacher concerning the teaching construction matters. The last suggestion is providing the supervisor with the same discipline in school if possible so the content of the lesson plan can be checked whether the lesson prepared is already aligned with learning objective and the discussion made will be meaningful because the supervisor can discuss the content of the lesson plan as well as any problems encountered by the Beginner EFL teacher in the teaching and learning process. Thus, teacher development for Beginner teachers will improve in schools.

\section{REFERENCES}

Airsian, P.W. 2000. Assessment in the Classroom: A Concise Approach. ( $2^{\text {nd }}$ Edition). Boston: McGraw-Hill.

Anies Baswedan sebut pendidikan Indonesia gawat darurat. Kompas. 1 Dec. 2014. http://edukasi.kompas.com/read/2014/12/01/13455441/Anies.Baswedan.Sebut.Pendidikan. Indonesia. Gawat.Darurat. Accessed Desember 2, 2014 at 20:40

Asf, J. and Mustofa, S. 2013. Supervisi Pendidikan: Terobosan Baru dalam Peningkatan Kinerja Pengawas Sekolah dan Guru. Jogjakarta: Ar-Ruzz Media.

Badan Standar Nasional Pendidikan. 2006. Panduan Penyusunan Kurikulum Tingkat Satuan Pendidikan Jenjang Pendidikan Dasar dan Menengah. Jakarta.

Bloom, B.S. et.al. 1956. Taxonomy of Educational Objectives. Handbook I: Cognitive Domain. London: Longmans

Bloom, B. S., et.al. 1964. Taxonomy of Educational Objectives. Handbook II: Affective Domain. London: Longmans

Brown, G. 1975. Micro Teaching. A Programme of Teaching Skills. London: Harper and Row

Brown, H. D. and Abeywickrama, P. 2010. Language Assessment: Principles and Classroom Practices. New York: Pearson Education.

Brown, H. D. 2007. Principles of Language Learning and Teaching. ( $5^{\text {th }}$ Edition). New York: Pearson Education

Brown, J.D. 1995. The Elements of Language Curriculum. A Systematic Approach to Program Development. Boston: Heinle and Heinle

Callahan, J.F, Clark, L.H., and Kellough, R.D. 2002. Teaching in the Middle and Secondary Schools. ( $7^{\text {th }}$ Edition). New York: Pearson Education.

Callahan, J. F. and Clark, L. H. 1988. Teaching in the Middle and Secondary Schools: Planning for Competence ( $3^{\text {rd }}$ Edition). New York: MacMillan

Cangelosi, J.S. 1992. Systematic Teaching Strategies. New York: Longman.

Chambers, G.N. 1999. Motivating Language Learners. Clevedon: Multilingual Matters Ltd.

Clandinin, D. 1992. Narrative and story in teacher education. In T.Russell \& H. Munby (Eds.), Teachers and teaching: From classroom to reflection (p.124-137). London: Falmer. 
Clark, C. M., and Yinger, R. J. 1987. Teacher Planning, In J. Calderhead (Ed.), Exploring Teachers' Thinking (p.84-103). London: Cassell.

Clark, C. M. and Peterson, P. 1986. Teachers' Thought Processes. In M. C. Wittrock (Ed.), Handbook of research on teaching ( ${ }^{\text {rd }}$ Edition) (p.255-296). New York: Macmillan

Cresswell, J. W. 2004. Educational Research: Planning, Conducting, and Evaluating Quantitative and Qualitative Research. (3rd Edition).

Cruickshank, D.R., et.al. 2014. Perilaku Mengajar (The Act of Teaching). Jakarta: Salemba Humanika.

Cunningham, W.G. 1982. Systematic Planning for Educational Change, ( $1^{\text {st }}$ ed.). California: Mayfield Publishing

Depdiknas. 2006a. Kurikulum Tingkat Satuan Pendidikan (KTSP) [Online]. http://ktsp.diknas.go.id/ktsp sma.php. Accessed June $13^{\text {th }} 2012$ at 7:20 P.M

Diorio, J. 1982. Knowledge, autonomy, and the practice of teaching, Curriculum Inquiry, 12(3), p.257-282.

Dornyei, Z. 2001. Motivational Strategies in the Language Classroom. Cambridge: Cambridge University Press 2001. Teaching and Researching Motivation. London: Pearson Education

Ely, D. P. 1978. Instructional Design and Development. New York: Syracuse University Publisher

Ennis, C.D. 1994. Knowledge and beliefs underlying curricular expertise. Quest, 46, p.164-175.

Farrell, T. S. C. 2002. Lesson Planning. In J. C. Richard and W. A. Renandya (Eds.), Methodology in Language Teaching: An Anthology of Current Practice (p.30-39), New York: Cambridge.

Freeman, D. 1996. Redefining the Relationship between Research and What Teachers Know. In K. M. Bailey \& D. Nunan (Eds.). Voices from the Language Classroom: Qualitative Research in Second Language Classrooms (p.88-115). New York: Cambridge.

Gagne, R.M., Briggs, L.J. 1979. Principles of Instructional Design. (2 ${ }^{\text {nd }}$ Edition). New York: Holt, Rinehart and Winston.

Gall, J. P., Gall, M. D., and Borg, W. R. 2005. Applying Educational Research: A Practical Guide. (5 ${ }^{\text {th }}$ Edition). Boston: Pearson Education.

Gebhard, J. G. 1996. Teaching English as a Foreign or Second Language: A Teacher Selfdevelopment and Methodology Guide. Michigan: University of Michigan Press.

Gronlund, N.E. 2000. How to Write and Use Instructional Objectives. (6 ${ }^{\text {th }}$ Edition). New Jersey: Prentice-Hall

Harmer, J. 2007. The Practice of English Language Teaching ( $4^{\text {th }}$ Edition). New York: Pearson Education

Harwood, N. 2010. Issues in Material Development and Design. In N. Harwood (Ed.), English Language Teaching Materials: Theory and Practice (p.3-30). New York: Cambridge University Press

Hamanik, O. 2009. Proses Belajar Mengajar. Jakarta: Bumi Aksara.

Hughes, A. 2003. Testing for Language Teachers. ( $2^{\text {nd }}$ Edition). Cambridge: Cambridge University Press

Hunter, M. 1994. Mastery Teaching. In Black, J.H. Everson, S.T. and Guskey, T.R. (Eds.) School Improvement Programs (p.181-204). New York: Scholastic.

1992. Mastering Teaching: Increasing Instructional Effectiveness in Secondary Schools, Colleges, and Universities. California: TIP Publication. 
Jabu, B. 2008. English Language Testing. Makassar: Badan Penerbit UNM

Jalal, F., Samani, M. et al. 2009. Teacher Certification in Indonesia: A Strategy for Teacher Quality Improvement. National for Higher Education. Jakarta.

Jalongo, M. R., Rieg, S. A., and Helterbran, V. R. 2007. Planning for Learning: Collaborative Approaches to Lesson Design and Review. New York: Columbia Univ.

Johnson, D.W. \& Ahlgren, A. 1976. Relationship between student attitudes about cooperation and competition and attitudes toward schooling. Journal of Educational Psychology, 68(1), 92-102.

Kaufman, R. A., and English, F. W. 1979. Need Assessement: Concept and Application. Englewood Cliffs: Educational Technology Publication

Keller, J.M. 2010. Motivational Design for Learning and Performance: The ARCS Model Approach. New York: Springer

Krathwohl, D. R. et.al. 1964. Taxonomy of Educational Objectives. Handbook II: Affective Domain. New York: David McKay Company Inc.

LeCompte, M. D., \& Preissle, J. (1993). (2nd ed.). Ethnography and qualitative design in educational research. San Diego, CA: Academic Press.

Livingstone, C. and Borko, H. 1989. Expert-Novice Differences in Teaching: A Cognition Analysis and Implications for Teacher Education. Journal of Teacher Education, 40 (4), 36-42.

Martiono. 2012. Perencanaan Pembelajaran. Suatu Pendekatan Praktis Berdasarkan KTSP Termasuk Model Tematik. Yogyakarta: Aswaja

Marzano, R. 2010. On Excellent in Teaching. Indiana: Solution Tree.

Masnur, M. 2007. KTSP: Pembelajaran Berbasis Kompetensi dan Kontekstual. Panduan Bagi Guru, Kepala Sekolah dan Pengawas Sekolah. Jakarta: Bumi Aksara

McCutcheon, G. and Milner, H.R. 2002. A Contemporary Study of Teacher Planning in a High School English Class. Teachers and Teaching: theory and practice, 8(1), 8194. Carfax publishing.

McKay, S.L. 2002. Teaching English as an International Language. Oxford Handobook for Language Teachers. Oxford: Oxford University Press

McMillan, J.H. 2004. Classroom Assessment: Principles and Practice for Effective Instruction. ( $3^{\text {rd }}$ Edition). Boston: Pearson Education.

Merriam, S. B., et al. 2002. Qualitative Research in Practice: Examples for Discussion and Analysis. San Francisco: Jossey-Bass.

1998. Qualitative Research and Case Study Applications in Education: Revised and Expanded from Case Study Research in Education. San Francisco: Jossey-Bass.

1988. Case Study Research in Education: A Qualitative Approach. San Francisco: Jossey-Bass.

Moore, K.D. 2005. Effective Instructional Strategies: From Theory to Practice. California: Sage.

Morrison, G.R., Ross, S.M., and Kemp, J.E. 2006. Designing Effective Instruction. New York: John Wiley and Sons.

Mulyasa, E. 2006. Kurikulum yang Disempurnakan: Pengembangan Standar Kompetensi dan Kompetens Dasar. Bandung: Rosda

Mustikawati, Y. 2018. EFL Teachers' Lesson Planning Competence: A Case study on Lesson Planning Competencies of the Beginner EFL Teachers at Public Senior High Schools in Makassar (Unpublished doctoral dissertation). Universitas Negeri Makassar, Makassar, Indonesia. 
Nelson, K.L., Price, K.M. 1999. Daily Planning for Today's Classroom. A Guide for writing Lesson and Activity Plans. Belmont, CA: Wadsworth Publishing Company

Nunan, D. 1989. Designing Tasks for the Communicative Classroom. Cambridge: Cambridge University Press

Nunan, D. and Lamb, C. 1996. The Self-Directed Teacher: Managing the Learning Process. New York: Cambridge.

Nunan, D. 1992. Designing Tasks for the Communicative Classroom. New York: Cambridge.

1991. The Learner-Centered Curriculum: A Study in Second Language Teaching. New York: Cambridge.

Olson, M.R. 1995. Conceptualizing narrative authority: Implications for teacher education. Teaching and Teacher Education, 11, p.119-135.

Peraturan Menteri Pendidikan Nasional Nomor 22 Tahun 2006. Nomor 23 Tahun 2006.

Nomor 41 Tahun 2007.

Perrot, E. 1982. Effective Teaching. A Practical Guide to Improving Your Teaching. London: Longman

Prajas, A.A.H. 2009. Analysis on the Lesson Plan of English Speaking Class based on School-based Curriculum at Public Senior High Schools in Malang. [online], http://letsseesky.wordpress.com/2009/04/04/analysis-on-the-lesson-plan-ofenglish-speaking-class-based-on-school-based-curriculum-sbc-at-public-seniorhigh-schools-in-malang accessed June 10th 2013 P.M

Pujiono. (2013). The Analysis of Lesson Plan by the English Teachers of Senior High Schools in kudus in the Academic Year 2012/2013. [online], http://eprints.umk.ac.id/1710/1/Hal.pdf accessed February 13th 2014 08:25 P.M

Price, K.M. and Nelson, K.L. 1999. Daily Planning for Today's Classroom: A Guide for Writing Lesson and Activity Plans. California: Wadsworth.

Quina, J. 1989. Effective Secondary Teaching: Going Beyond the Bell Curve. New York: Harper \& Row.

Reynolds, M.C. 1989. Knowledge Base for the Beginner Teacher. New York: Pergamon.

Richards, J. C. 1998. What is the Use of Lesson Plans? In J. C. Richards (Ed.). Beyond training (p.103-121). New York: Cambridge.

Richard, J. C. and Renandya, W. A. 2002. Methodology in Language Teaching: An Anthology of Current Practice. New York: Cambridge.

Richard, J. C. and Rodgers, T. S. 2001. Approaches and Methods in Language Teaching ( $2^{\text {nd }}$ Edition). Cambridge: Cambridge University Press

Ritchie, J. and Lewis, J. 2003. Qualitative and Research Practice: A Guide for Social Science Students and Researchers. London: Sage Publication.

Robbins, S. P. 1982. The Administrative Process. ( $2^{\text {nd }}$ ed.). New Delhi: Prentice-Hall of India.

Rovegno, I. 2003. Teachers' knowledge construction, In S. Silverman \& C. Ennis (Eds.) Student learning in physical education: Applying research to enhance instruction, (pp.295-310). Champaign, IL: Human Kinetics.

Sansone, C. and Harackiewicz. 2000. Intrinsic and Extrinsic Motivation: The Search of Optimal Motivation and Performance. San Diego: Academic Press.

Saud, U.S. 2009. Pengembangan Profesi Guru. Jakarta: Alfabeta.

Schoenfeldt, M.K. and Salsbury, D.E. 2009. Lesson Planning: A Research-Based Model for K-12 Classrooms. New Jersey: Pearson Education. 
Skehan, P. 1989. Individual Differences in Second-Language Learning. New York: Routledge, Chapman, and Hall, Inc.

Skowron, J. 2006. Powerful Lesson Planning: Every Teacher's Guide to Effective Instruction ( $2^{\text {nd }}$ Edition). California: Corwin.

Shrum, J.L. and Glisan, E.W. 2010. Teacher's Handbook: Contextualized Language Instruction. ( $4^{\text {th }}$ edition). Boston, MA: Heinle.

Shulman, L. S. 1986. Those Who Understand: Knowledge Growth in Teaching. Educational Researcher, 15 (2), 4-14.

Sparks-Langer, G. and Colton, A. 1991. Synthesis of Research on Teacher's Reflective Thinking. Educational leadership, 48 (6), 37-44.

The Praxis Series, Professional Assessments for Beginner Teachers. 2001. Praxis III: Classroom performance assessments, orientation guide. New York: ETS (Educational Testing Service).

Strevens, P.D.1987. The Nature of Language Teaching. In Long, M. H. and Richards, J.C. (Eds), Methodology in TESOL: A Book of Reading. U.S.A.: Newbury House Publishers.

Tyler, R.W. 1949. Basic Principles of Curriculum and Instruction. Chicago: University of Chicago Press.

Undang-Undang Republik Indonesia Nomor 14 Tahun 2005 Tentang Guru dan Dosen. 2006. Jakarta: CV. Eko Jaya

Uno, H.B. 2010. Perencanaan Pembelajaran. Jakarta: Bumi Aksara.

. 2008. Profesi Kependidikan: Problema, Solusi dan Reformasi Pendidikan di Indonesia. Jakarta: Bumi Aksara.

Veenman, S. 1984. Perceived Problems in Beginner Teachers. Review of Educational Research, 54 (2), 143-178.

Widiastuti, I. A. Md. S, Padmadewi, N. N., Artini, L. P. 2013. A Study on the Implementation of English School Based Curriculum in SMAN 5 Denpasar. [online], http://pasca.undiksha.ac.id/e-journal/index.php/jpbi/article/view/577 accessed September $5^{\text {th }} 2014$ 10:23 A.M

Wiggins, G. and McTighe, J. 2005. Understanding by Design. (Expanded $2^{\text {nd }}$ Edition). New Jersey: Pearson Education

Wiles, J. and Bondi, J. 1996. Supervision: A Guide to Practice. New Jersey: A Simon \& Schuster Company.

Winaryati, E. 2014. Evaluasi Supervisi Pembelajaran. Yogjakarta: Graha Ilmu.

Yamin, M. 2013. Desain Pembelajaran Berbasis Tingkat Satuan Pendidikan. Jakarta: Referensi (Gaung Persada Press Group)

Yinger, R. J. 1980. A Study of Teacher Planning. Elementary School Journal, 80 (3), 107127.

Zahorik, J.A. 1975. Teachers' Planning Models. Educational Leadership, 33, 134-139 